\title{
Blast design for improved performance and reduced surface vibration - a case study
}

A Eremenko Chinakal Institute of Mining of the Siberian Branch of the Russian Academy of Sciences, Russia

\begin{abstract}
Deeper level iron ore mining at a depth below 800-1,000 $\mathrm{m}$ in Western Siberia faces poor ground conditions and heavily complicated geomechanical conditions. Ore extraction involves such systems as level caving, room-and-pillar mining with and without backfilling and sublevel caving. Blast designs involve closely spaced rings of blastholes with a diameter from 89 to $250 \mathrm{~mm}$.

Aiming to evaluate drilling-and-blasting parameters, researches have been undertaken to assess effects of blast patterns on quality of rock fragmentation by explosive charges and on rates of dynamic and seismic events. It is found that room-and-pillar mining with and without backfilling with different design factors allows enhancing efficiency and safety of stoping. The author has proposed a blasting technique and a method to determine powder factor per each blasthole with regard to geotechnical conditions in a mine.

The application of the designed blast patterns enables reduction in powder factor by $20-30 \%$, decreases yield of oversize by 15-20\%, lowers amplitudes of the stope floor and ground surface vibrations and reduces seismic energy from $10^{6}$ to $10^{4} \mathrm{~J}$.
\end{abstract}

Keywords: rockburst hazard, seismicity, blast pattern, reduced powder factor, seismic energy

\section{Introduction and brief geology of iron ore fields in Western Siberia}

One of the zones of the regional Altai-Sayan Fold Belt in Western Siberia-Gornaya (Mountainous) Shoria-holds the richest iron ore deposits of Tashtagol and Sheregesh (Figure 1). Tectonics of this area features chronically moving westward deep faults (Kuznetsov 1952; Ashurkov 1971; Kuznetsov 1963). Contiguous orebodies of Tashtagol and Sheregesh are part of the Kondom group of iron ore deposits. Total ore reserves are 400-452 million tonnes and make up 1 billion tonnes if combined with predicted reserves (Kalugin et al. 1981). There are 14 production sites within the two deposits (South-Western, Eastern, Main, Swampy, New Sheregesh, Understream and others).

The ore fields are proven down to the depth of $1,200 \mathrm{~m}$ below the ground surface. Jointing is highly developed and is observed in underground excavations. Tectonic fracturing shows itself as zones of jointing, degradation, shearing, tectonic clay and slickensides, or is healed with calcite and shearing material (Figure 2). It is found that principal stresses in rock mass beyond the influence zone of mining are: $\sigma_{1}=2.6 \gamma \mathrm{H} ; \sigma_{2}=1.4 \gamma \mathrm{H} ; \sigma_{3}=\gamma \mathrm{H}$, where $\gamma$ is the bulk weight of rocks and $\mathrm{H}$ is the depth below the ground surface. The local tectonics is characterised by strike-slip and dip-slip faulting, with dip angles of $40^{\circ}-85^{\circ}$ and displacement from 40 to $300 \mathrm{~m}$. Numerous openings of discission have different angles of dip and strike, both with displacement of ore bodies and enclosing rocks to $10 \mathrm{~m}$ and without. The occurrence of ore and rocks is conformable, the ore zone has a sublatitudinal stretch and its occurrence depth changes east-westward from 200 to $900 \mathrm{~m}$ below surface. The length of the ore zone is $3.5 \mathrm{~km}$ along the strike, and its thickness varies from 40 to $200-300 \mathrm{~m}$. 


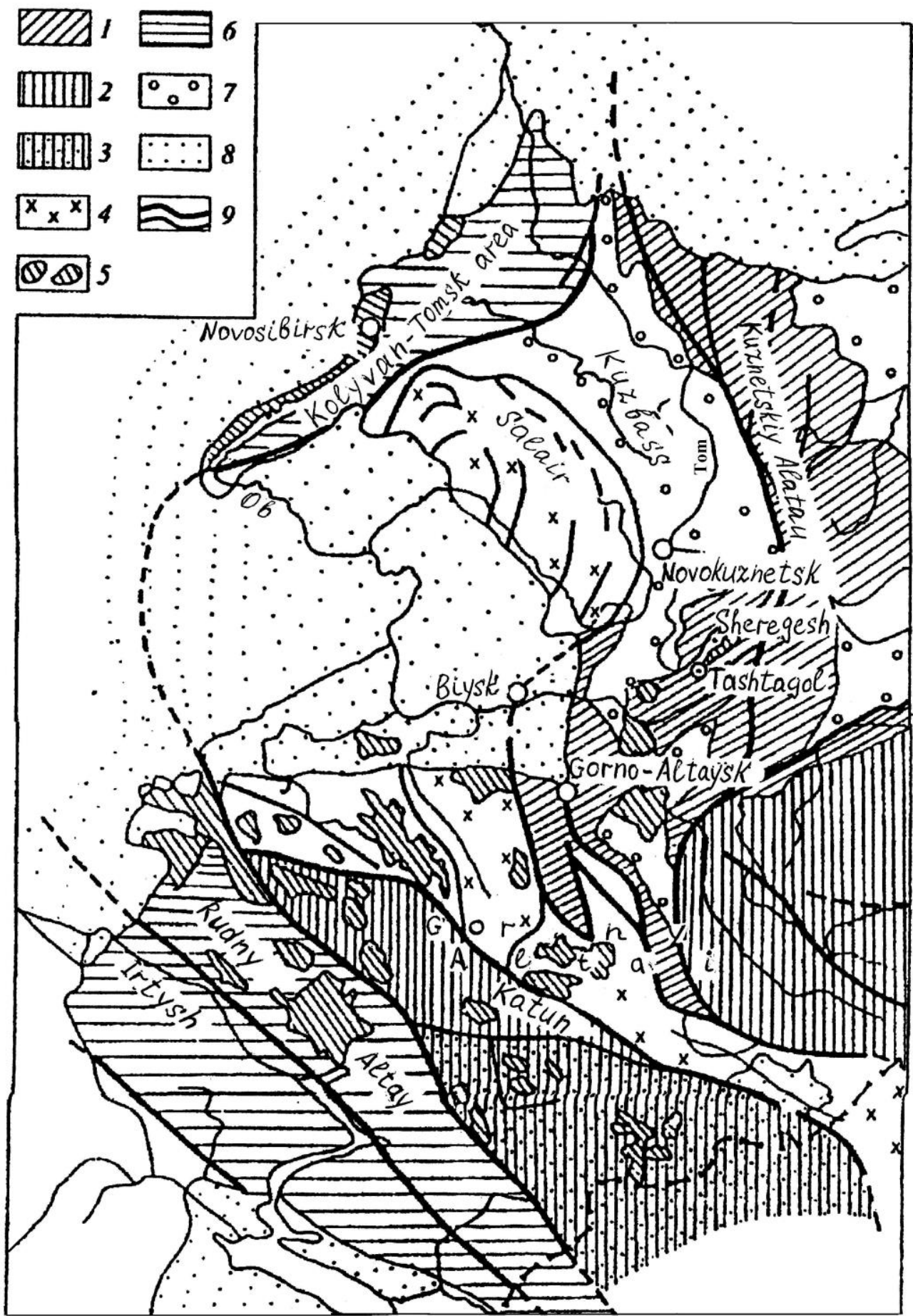

Figure 1 Altai-Sayan Fold Belt (by Kuznetsov 1952): 1-zones of Salair-Caledonian stabilisation phase; 2-Caledonian orogenesis zones; 3-Charysh-Terektin zone of Central Altai of Caledonian phase; 4-Anui-Chun Caledonian-Hercyan zone; 5-Hercyan granitoid sequences; 6-Hercyan geosynclinals folded zones; 7-Hercyan depressions; 8-Meso-Cenosoic depression; 9-deep regional faulting

Figure 3 shows the arrangement of ore production sites at Sheregesh deposit.

New Sheregesh production site 8 (Figure 3) occurs deeper than Swampy site 9, at a distance of 200-300 m south-westward of it. Ore and rocks occurrence is conformable. The ore and limestone interface has a steep south-westward dip (at $70-80^{\circ}$ ), there is sharp wedging of a part of the orebody at a depth of 400-600 $\mathrm{m}$ while the rest of it occurs horizontally. 


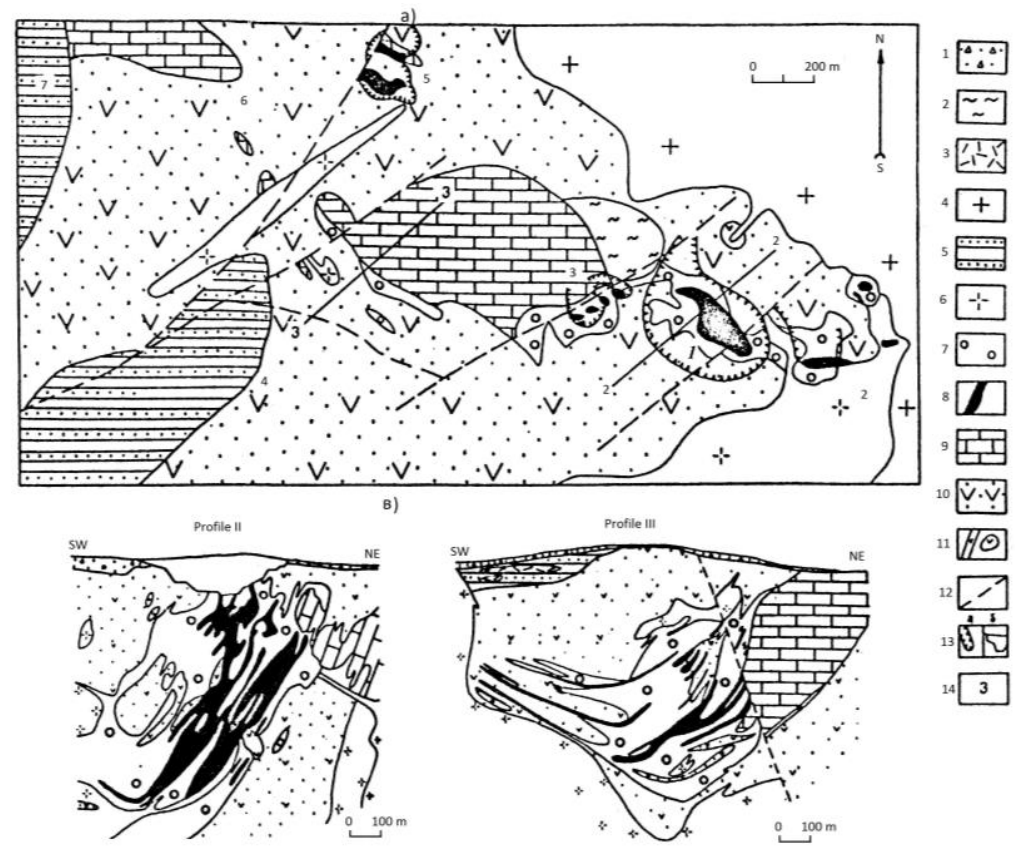

Figure 2 Geologic surface plan (a) and survey profiles II and III (b) at Sheregesh deposit: 1-diluvium; 2-karst; 3-quartz porphyry; 4-granites; 5-Ordovician quarzty sandstone and siltstone; 6-syenite; 7-skarn; 8-magnetite ore; 9-11-Mid-Cambrian formations (9-marmorised limestone; 10-tuff and lava of andesitic porphyry and keratophyre; 11-pyroxene and amphibole porphyry); 12-fractures; 13 -boundaries of open pit mine; 14-underground production sites (1-Main; 2-Eastern; 3-Swampy; 4-New Sheregesh; 5-Mining; 6-Undesrtream; 7-New Site)

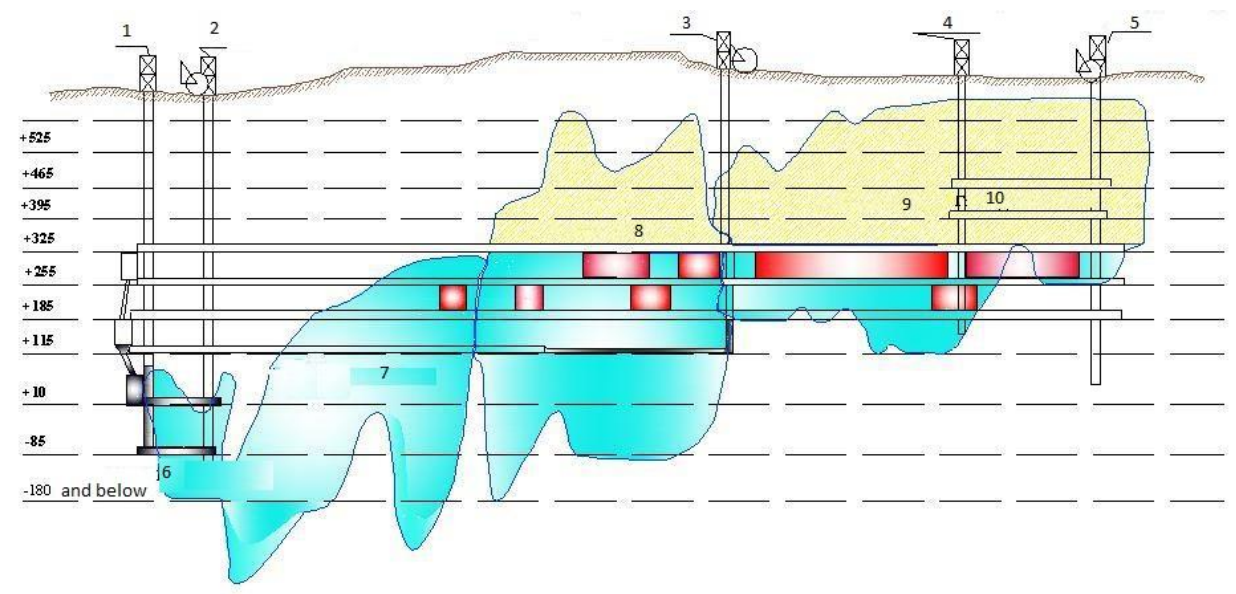

Figure 3 Production sites at Sheregesh iron ore deposit: +525 down to $-180 \mathrm{~m}$ are levels in the mine: 1-Skip shaft; 2-New cage shaft; 3-Air outlet shaft; 4-Main shaft; 5-Eastern shaft; 6-New site; 7-Understream; 8-New Sheregesh; 9-Swampy; 10-Main

\section{$2 \quad$ Blast design for high-stress ore mining}

At deeper level mining at a depth of 800-1,000 m and below, ground conditions are more challenging. Mining is carried out with level caving, room-and-pillar mining and sublevel caving. Where exploitation is undertaken using caving methods, production blocks have the following parameters:

$$
\text { length } 37-65 \mathrm{~m} \text {; width } 27 \mathrm{~m} \text {; height } 50-74 \mathrm{~m} \text {. }
$$

A slot raise is $5 \mathrm{~m}$ wide (Figure 4). Ore reserves contained in the blocks to be caved vary from 150,000 to 400,000 tonnes. Powder factor is $0.53-0.67 \mathrm{~kg} / \mathrm{t}$. Burden is $4-7.5 \mathrm{~m}$ in blasting towards the slot raise and is 
4-5.5 $\mathrm{m}$ in choke blasting. The spacing/burden ratio for blastholes is 1.1-1.2. The number of blastholes $105 \mathrm{~mm}$ in diameter is varied from six to 16 per ring. Undercutting of the production blocks is made with flat bottom and by trenches. Blasting at the top of a production blocks uses rings of horizontal blastholes. Blasting technique in a production block uses:

- Short delays of $25 \mathrm{~ms}$.

- V-shaped blast pattern.

- Side-to-side blasting (in the middle of the block, transverse to its strike).

- Wavy pattern (from free surface depthward the block, with blasthole pattern making a sinuous line).
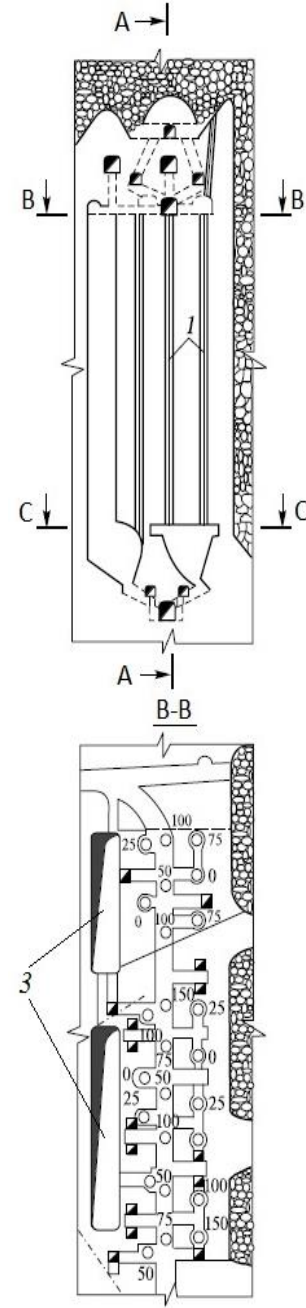

A-A
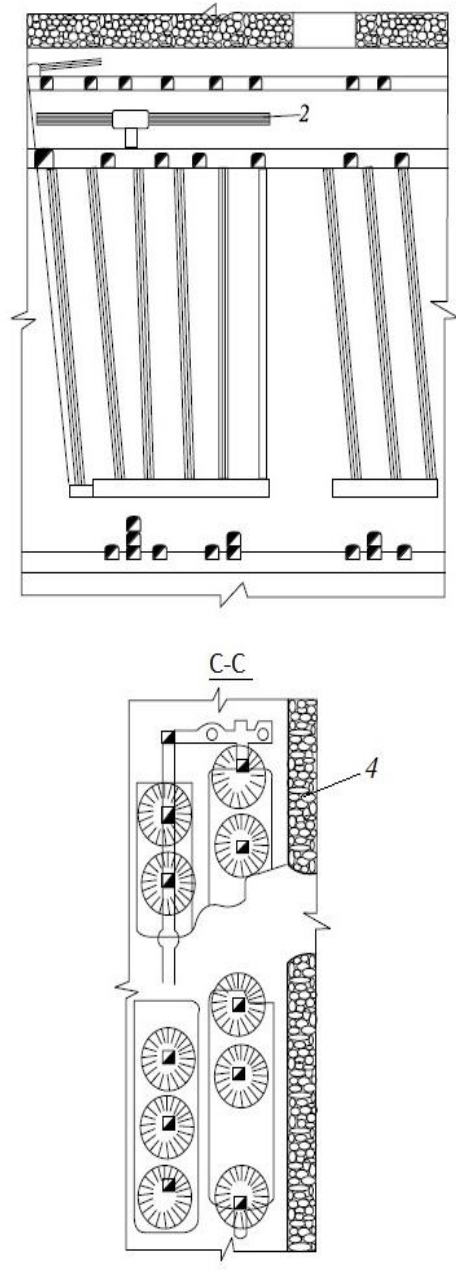

Figure 4 Pattern of multi-row close-spaced blastholes in the system of mining with level caving: 1 and 2 are vertical and horizontal closely spaced blastholes; 3 are compensation chambers; 4 is pre-blasted rock mass; $\mathbf{0 - 1 5 0 ~ m s ~ a r e ~ d e l a y ~ i n t e r v a l s ~}$

With such pattern of parallel closely spaced blastholes, the yield of oversize fragments has lowered from $8 \%$ to $3.5-4.7 \%$. Increasing the diameter of blastholes (from 105 to $250 \mathrm{~mm}$ ) has allowed:

- Higher ore recovery (by $25 \%$ ) per $1 \mathrm{~m}$ of blasthole.

- Halved overbreak.

- Enhanced drilling efficiency by 1.3 times.

It has been found that room-and-pillar mining with and without backfilling improves safety and efficiency of mining operations. It is proposed to perform room-and-pillar with alternating arrangement of rooms and 
temporal safety pillars as this pattern contributes to stress relief as follows from the analyses undertaken (Eremenko et al. 2015).

For the conditions of Sheregesh deposit, the author has evaluated the room-and-pillar mining design with alternating arrangement of rooms and temporal safety pillars in terms of the southeastern orebody at a level above $+255 \mathrm{~m}-$ an area that can be considered a high rockburst-hazardous zone (Figure 5). Based on the theoretical evaluation, a rational sequence of room-and-pillar mining has been accepted: the first stage is mining across the strike of the orebody and the second stage is side-to-side mining along the strike.
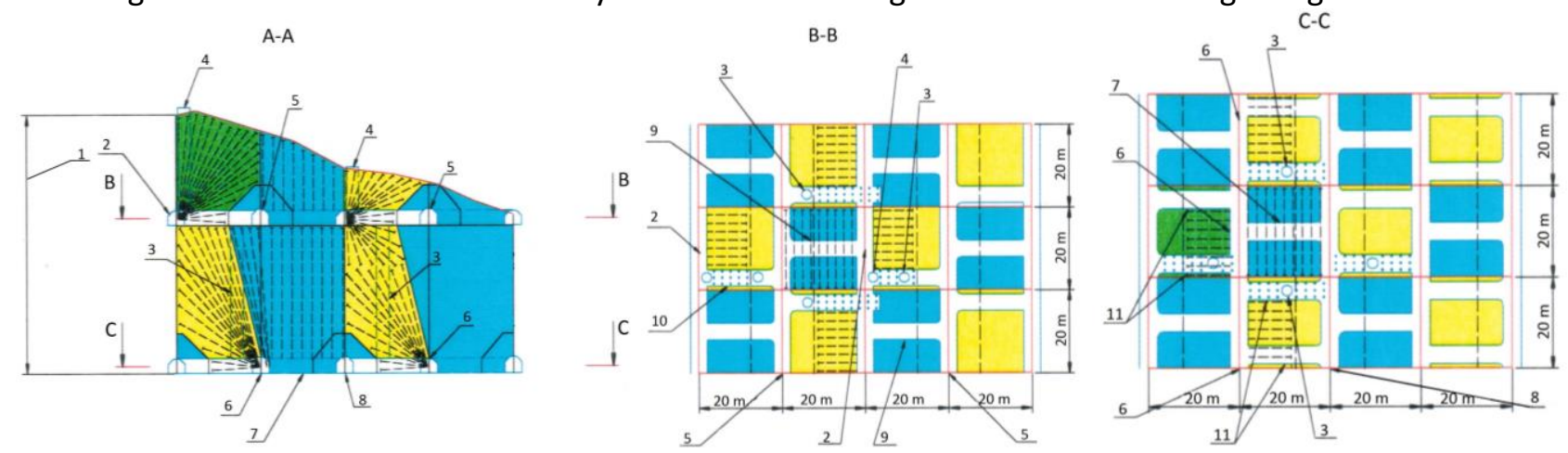

Figure 5 Scheme of mining with alternating rooms and pillars: 1-average thickness $45 \mathrm{~m}$; 2-sublevel drilling drift of a room; 3-raise slot of lower sublevel of a room; 4-raise slot of upper sublevel of a room; 5-sublevel transport drift; 6-drilling drift of a room; 7-drilling crosscut of a pillar; 8-transport drift; 9-sublevel drilling crosscut of a pillar; 10-sublevel loading access in a room; 11 -loading access in a room

For the ground conditions of the southwestern orebody below the level of $+255 \mathrm{~m}$ under high horizontal stresses, the developed design of sublevel caving assumes dividing the ore zone into production blocks across its strike (Figure 6). The blocks are $45 \mathrm{~m}$ high, $40 \mathrm{~m}$ long and $20 \mathrm{~m}$ wide. Produced ore is discharged at the end of a drilling cross-cut and via diagonal access roads using load-haul-dumpers.

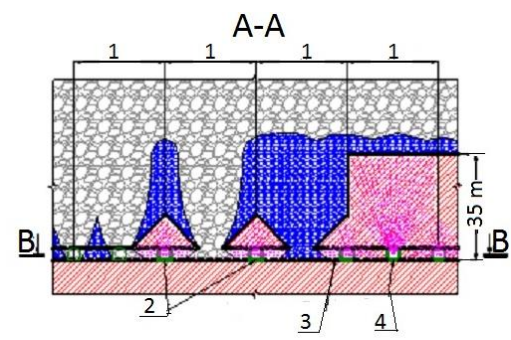

B-B

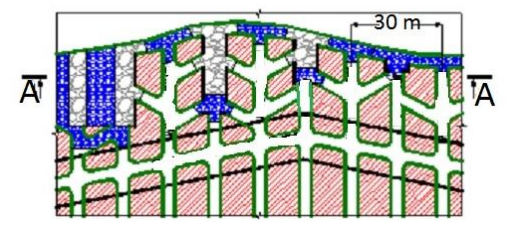

Figure 6 Sublevel caving with one-stage blasting and full-area ore discharge

This design of mining with alternating rooms and pillars makes it possible, at the sustained stability of span of mined-out void, to:

- Diminish the rock damage zone owing to displacement of pillars relative one to the other and due to their arrangement across the strike of the orebody.

- Reduce the amount of development and face-entry drivage from 14.5 to $9.6 \mathrm{~m} 3$ per 1,000 $\mathrm{t}$ of rock mass by means of changing top-downward sequence of ore extraction, or by modifying mine design, e.g. size of rooms and pillars $20 \times 20 \mathrm{~m}$.

- Bring down powder factor from 0.15 to $0.1 \mathrm{~kg} / \mathrm{t}$. 
The blasting pattern includes rings of blastholes with a diameter of 89 and $105 \mathrm{~mm}$. The powder factor per a charge is given by:

where:

$$
q_{b}=10^{-3} \frac{(8.15-2.48 \log \alpha) \gamma^{2} K_{g t}}{\log \alpha\left(10^{3} q_{2}+\gamma K_{g t}\right)}, \mathrm{t} / \mathrm{m}^{3},
$$

$\alpha=$ expansion angle of a cone generated in rocks by a blasted charge.

$v=$ density of rocks in the vicinity of a blasthole.

$q_{2} \quad=$ planned powder factor of secondary fragmentation by blasting.

$K_{g t}=$ coefficient of blasting conditions in a production block, which is found using the formula below:

$$
K_{g t}=0.52 \cdot 10^{-3} K_{p} K_{0} K_{b o} K_{b b} K_{n} \frac{f v \sqrt{m w}}{\sqrt{d_{b}^{3}}}
$$

where:

$$
\begin{aligned}
& K_{p}=\text { index of blasthole spacing, } \mathrm{m} . \\
& K_{0}=\text { index of rock hardness. } \\
& K_{b o}=\text { index of ore discharge at the block bottom. } \\
& K_{b b}=\text { index of explosive force. } \\
& K_{n}=\text { index of action of static stresses along the depth of mining. } \\
& f \quad=\text { rock hardness by Protodyakonov (equal to } 10 \mathrm{MPa} \text { ). } \\
& v \quad=\text { index of jointing. } \\
& m \quad=\text { index of blasthole spacing/burden ratio. } \\
& w \quad=\text { burden (m). } \\
& d_{b}=\text { assumable size of a fragment of broken rocks, } \mathrm{m} .
\end{aligned}
$$

Blastholes with smaller $\alpha$ should be initiated in advance of blastholes with larger $\alpha$ in a ring. Table 1 gives some explanation concerning the choice of these parameters.

Powder factor in sublevel caving and in room-and-pillar mining varies from 10 to $23 \mathrm{~g} / \mathrm{t}$ and from 2 to $7 \mathrm{~g} / \mathrm{t}$, respectively (Figure 7). By estimation, the powder factor in the room-and-pillar mining has been reduced as a consequence of the assumed blasting pattern.

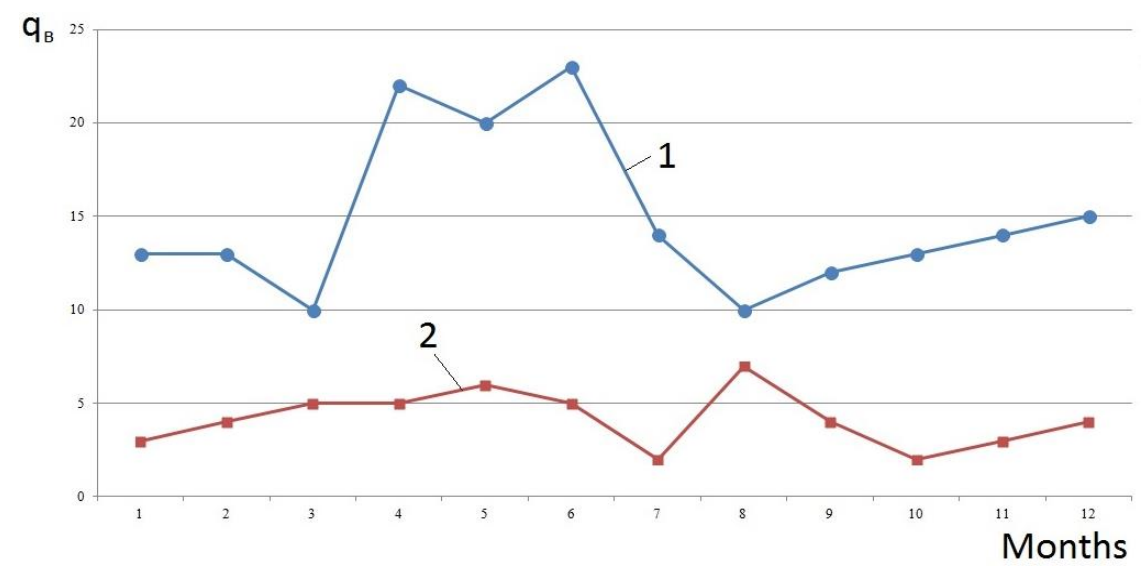

Figure 7 Powder factor in secondary fragmentation by blasting in different mining systems: 1—sublevel caving; 2-alternating rooms and pillars 
Table $1 \quad$ Blast design parameters

\begin{tabular}{|c|c|c|c|}
\hline Parameter & Description & $\begin{array}{l}\text { Unit of } \\
\text { measurement }\end{array}$ & Range \\
\hline$\alpha$ & $\begin{array}{l}\text { Expansion angle of a cone } \\
\text { generated by blasted charge }\end{array}$ & Degrees & $\begin{array}{l}\text { 0-360, assumed at the block blasting } \\
\text { design stage }\end{array}$ \\
\hline$\gamma$ & $\begin{array}{l}\text { Density of rocks in the vicinity of } \\
\text { a blasthole }\end{array}$ & $\mathrm{t} / \mathrm{m}^{3}$ & $\begin{array}{l}\text { Unrestricted; usually 2-7 depending } \\
\text { on a specific deposit }\end{array}$ \\
\hline$q_{2}$ & $\begin{array}{l}\text { Planned powder factor of } \\
\text { secondary fragmentation by } \\
\text { blasting }\end{array}$ & $\mathrm{t} / \mathrm{m}^{3}$ & $\begin{array}{l}\text { Unrestricted; assumed at mine } \\
\text { planning stage }\end{array}$ \\
\hline$K_{p}$ & Index of blasthole spacing & $\mathrm{m}$ & $\begin{array}{l}0.4-1.68, \text { assumed at mine planning } \\
\text { stage }\end{array}$ \\
\hline $\mathrm{K}_{\mathrm{o}}$ & Index of rock hardness & - & $\begin{array}{l}0.9 \text { at } f<10 \\
1 \text { at } f \geq 10\end{array}$ \\
\hline$K_{b o}$ & $\begin{array}{l}\text { Index of ore discharge at the } \\
\text { block bottom }\end{array}$ & - & $\begin{array}{l}0.9-1 \text {, assumed at mine planning } \\
\text { stage }\end{array}$ \\
\hline$K_{b b}$ & Index of explosive force & - & 0.8-1.9 (seldom higher) \\
\hline$K_{n}$ & $\begin{array}{l}\text { Index of action of static stresses } \\
\text { along the depth of mining }\end{array}$ & - & $\begin{array}{l}0.9-1.1 \text {, assumed at mine planning } \\
\text { stage }\end{array}$ \\
\hline$f$ & $\begin{array}{l}\text { Rock hardness by } \\
\text { Protodyakonov }\end{array}$ & - & $\begin{array}{l}\text { 1-20, assumed at mine planning } \\
\text { stage }\end{array}$ \\
\hline$u$ & Index of jointing & - & $0-1$, assumed at mine planning stage \\
\hline $\mathrm{m}$ & $\begin{array}{l}\text { Index of blasthole } \\
\text { spacing/burden ratio }\end{array}$ & - & $\begin{array}{l}0.8-1.0, \text { assumed at mine planning } \\
\text { stage }\end{array}$ \\
\hline w & Burden & $\mathrm{m}$ & $\begin{array}{l}\text { Unrestricted; usually } 0.5-10 \\
\text { depending on a specific deposit }\end{array}$ \\
\hline$d_{b}$ & $\begin{array}{l}\text { Assumable size of a fragment of } \\
\text { broken rocks }\end{array}$ & $\mathrm{m}$ & $\begin{array}{l}\text { Unrestricted; usually } 0.05-1 \\
\text { depending on a specific deposit }\end{array}$ \\
\hline
\end{tabular}

The drilling-and-blasting pattern rings of blastholes with a diameter of $89 \mathrm{~mm}$ at a powder factor of $1.64 \mathrm{~kg} / \mathrm{m}^{3}$ and a burden of $1.8 \mathrm{~m}$. It has been estimated that the powder factor in secondary fragmentation depends on the applied system of blind orebody mining (Figure 7). The powder factor ranges as $10-23$ and $2-7 \mathrm{~g} / \mathrm{t}$, respectively. Furthermore, the ore loss and dilution has been reduced down to 13.2 and $21.4 \%$, respectively.

\section{Seismic effect of production blasting}

A production blast had been carried out in block 3 at Level 140 to $-170 \mathrm{~m}$ on the eastern site of Tashtagol deposit. Total weight of explosive charge was $49.2 \mathrm{t}$. Ore reserves in this block equalled $168 \mathrm{t}$. Total length of blastholes with a diameter of $105 \mathrm{~mm}$ was $1,500 \mathrm{~m}$. Powder factor made $0.59 \mathrm{~kg} / \mathrm{t}$. Blasting delays were varied from 0 to 450 ms. Explosive weight per delay interval was ranged from 191 to 13,607 kg.

According to the data obtained from Tashtagol seismic station, the blast had energy class 7.4, or 74.1 $t$ in explosive equivalent. The seismic recording was aimed at determining the factual seismic effect on the nearby town of Tashtagol and on the rock mass in the area of the deposit (Kurlenya et al. 2014). Structures 
in Tashtagol town are box systems with bearing walls. Prior to the blast, conditions of residential buildings were in accord with security class II (which means that cracks in bearing structures are up to $0.5 \mathrm{~mm}$; cracks in brick structures and large blocks reach $3 \mathrm{~mm}$; uprightness of basements is violated; geometry is damaged to $40 \%$ ) in accordance to Russian Construction Norms and Regulations (USSR State Committee on Construction 1985). Allowable soil vibration due to any impact is specified as $1 \mathrm{~cm} / \mathrm{s}$ for public-purpose box systems with bearing walls (hospitals, schools, recreation centres) and $2 \mathrm{~cm} / \mathrm{s}$ for residential buildings (Glozman et al. 1982). Seismic recording was performed on 6 July 2014 at two points in Tashtagol town at a railway station and at a college. The applied procedure (Eremenko at al. 2002, 2005) is now widely applied in assessment of the seismic effect of large-scale blasting in mines of Evrazruda (Mashukov 2014).

The distance from the production blast to the recording point at the railway station is $400 \mathrm{~m}$ horizontally and $500 \mathrm{~m}$ height-wise; the absolute straight-line distance is $640 \mathrm{~m}$. The same figures for the recording point at the college are 4,200, 500 and $4,230 \mathrm{~m}$, respectively. Figure 8 presents the velocity seismograms for ground surface vibration obtained in the vertical and horizontal directions at the railway station after the above described production blast.
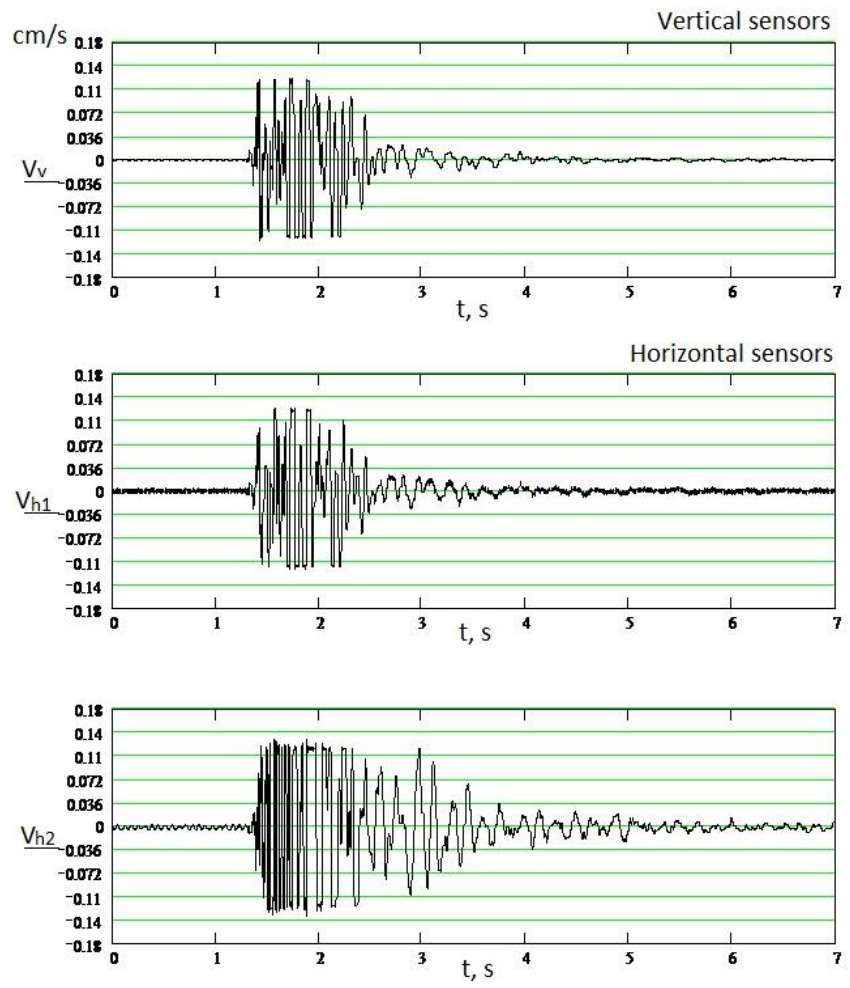

Figure 8 Velocity seismograms of ground surface vibration at the railway station

The first seismogram is obtained by a vertical seismic sensor and the peak velocity vibration is recorded as $0.12 \mathrm{~cm} / \mathrm{s}$. The second and third seismograms are recorded by the horizontal sensors oriented north-southward (towards the blast) and west-eastward, respectively. The duration of the vertical oscillations is $2.5 \mathrm{~s}$; the maximum amplitude high-frequency impulse has a duration of $1 \mathrm{~s}$ and the main low-frequency impulse with the amplitude of $0.04 \mathrm{~cm}$ has a duration of $1.5 \mathrm{~s}$.

The velocity seismogram of horizontal vibration of ground surface recorded by the sensor oriented toward the blast is analogous to the velocity seismogram of vertical vibration in amplitude and duration. The velocity seismogram of horizontal vibration in the transverse direction relative to the blast is essentially different: overall duration of seismic oscillations is $4.5 \mathrm{~s}$ and there is a high-amplitude low-frequency impulse. The high-frequency impulse has an amplitude of $0.12 \mathrm{~cm} / \mathrm{s}$ and a duration of $1 \mathrm{~s}$; it is followed by the low-frequency impulse with a high amplitude of $0.12 \mathrm{~cm} / \mathrm{s}$ and a duration of $1.5 \mathrm{~s}$. Then, the oscillation amplitude lowers to $0.02 \mathrm{~cm} / \mathrm{s}$ within $2 \mathrm{~s}$. 
The seismograms of seismic acceleration at the recording point at the railway station are shown in Figure 9. For vertical vibration, the acceleration is $36 \mathrm{~cm} / \mathrm{s}^{2}$ at the first second in the high-frequency range of the signal. For horizontal vibration, the acceleration is halved and equals $16 \mathrm{~cm} / \mathrm{s}^{2}$.
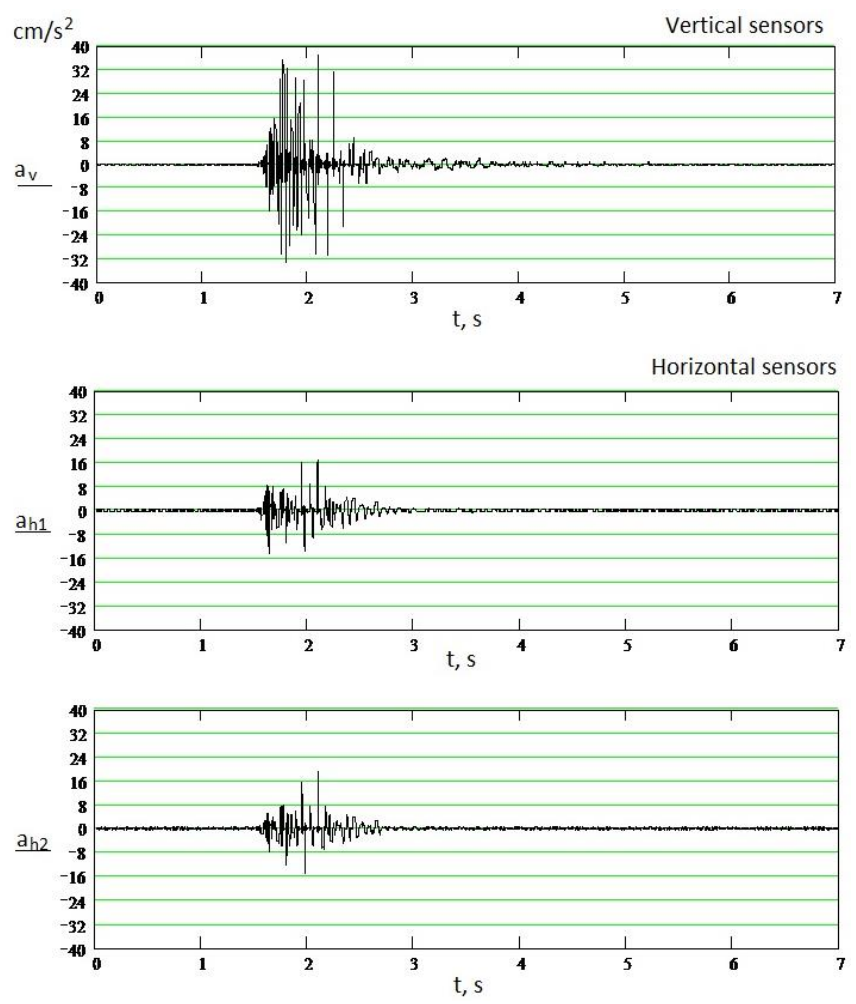

Figure 9 Seismic acceleration of ground vibration at the recording point at the railway station after the production blast

The displacement seismograms of ground vibration are given in Figure 10. The maximum displacement in the range of $0.016 \mathrm{~cm}$ is observed for vertical vibration, the displacements for horizontal vibration are $0.02 \mathrm{~cm}$.
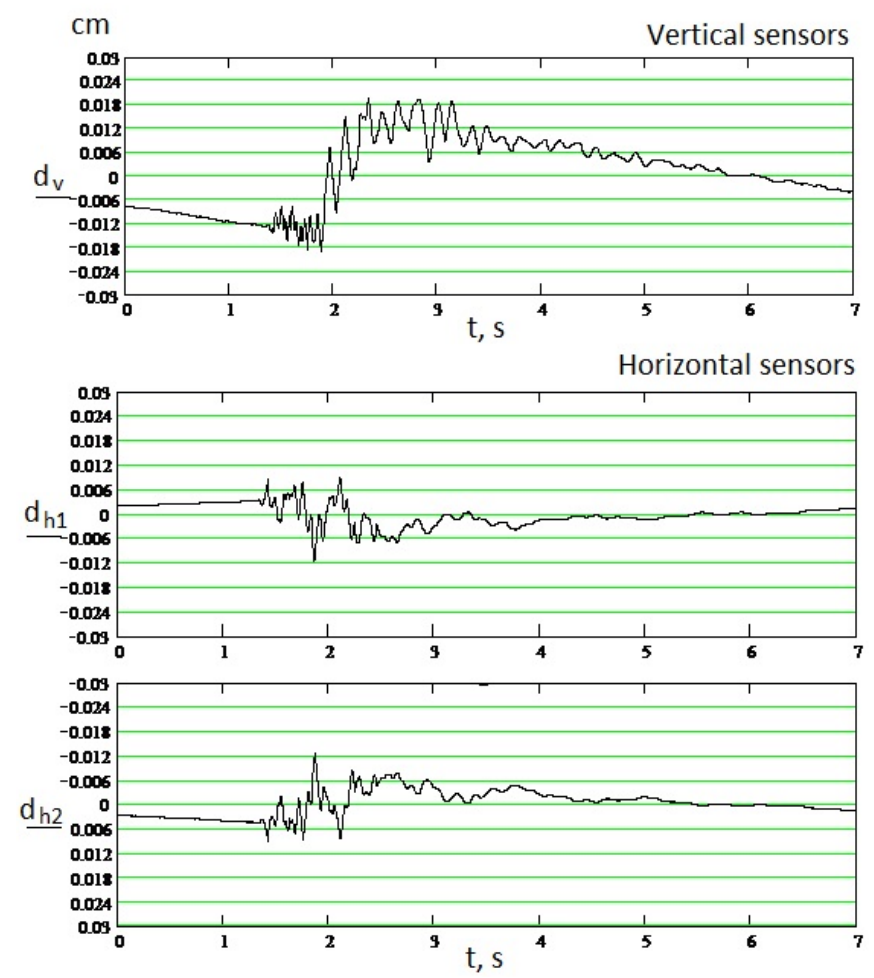

Figure 10 Displacement seismograms for ground vibration at the railway station after the production blast 
Based on the obtained amplitude-frequency response characteristics of ground surface vibration after the production blast (Figure 11), it has been found that the peak vertical vibrations have frequencies 1, 2, 3, 6 and $10 \mathrm{~Hz}$. For horizontal vibration, it is typical that peak oscillations have frequencies $1,5 \mathrm{and} 6 \mathrm{~Hz}$ and there are no vibrations within $10 \mathrm{~Hz}$ frequency.
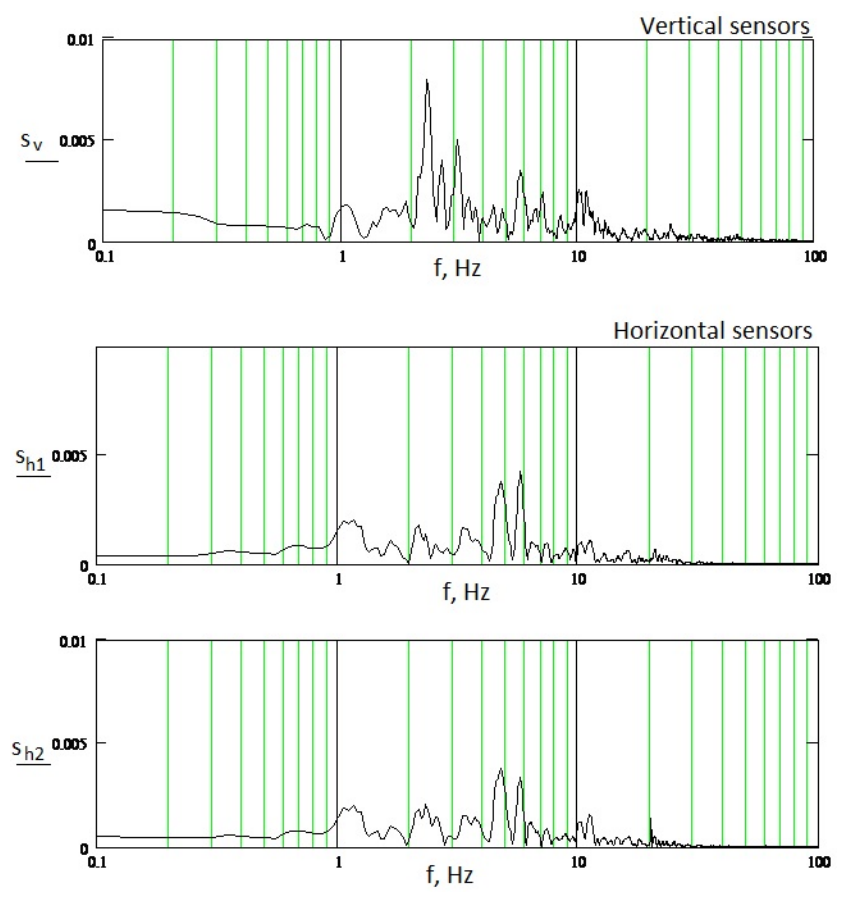

Figure 11 Amplitude-frequency response characteristics of seismic vibration of ground surface at the railway station after the production blast

The velocity seismograms for ground vibration at the second recording point at a college are presented in Figure 12.
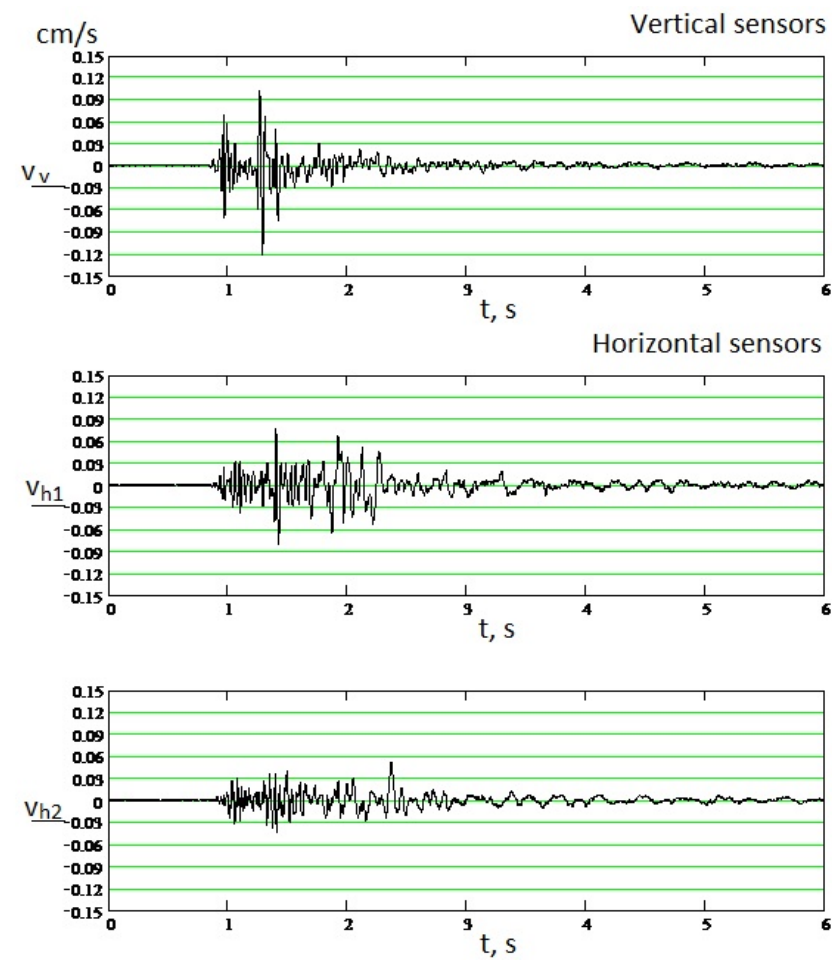

Figure 12 Velocity seismograms of ground surface at the recording point at the college after the production blast 
The maximum velocity and duration of horizontal vibration of the ground surface in the direction towards the production blast is $0.08 \mathrm{~cm} / \mathrm{s}$ and $3.5 \mathrm{~s}$, respectively. The maximum velocity of horizontal vibration in the north-southward direction is $0.05 \mathrm{~cm} / \mathrm{s}$ at a duration of $3.5 \mathrm{~s}$.

The acceleration seismograms for ground surface vibration at the recording point at the college are shown in Figure 13. The vertical vibration had a maximum acceleration of $3.2 \mathrm{~cm} / \mathrm{s}^{2}$, while the horizontal vibration oriented west-eastwards, towards the production blast, had a maximum acceleration twice as much at $7.2 \mathrm{~cm} / \mathrm{s}^{2}$. This orientation conforms with the direction of blasting. For the horizontal vibration in the line of north-south, the maximum acceleration is $4.8 \mathrm{~cm} / \mathrm{s}^{2}$. The displacement seismograms for the ground vibration after the large-scale blast are shown in Figure 14.

The maximum displacements are observed under the horizontal vibration in the direction towards the production blast and make $0.01 \mathrm{~cm}$; the displacements for the horizontal vibration in the north-south line are $0.004 \mathrm{~cm}$. The maximum displacement for the vertical vibration is minor and equals $0.0018 \mathrm{~cm}$.
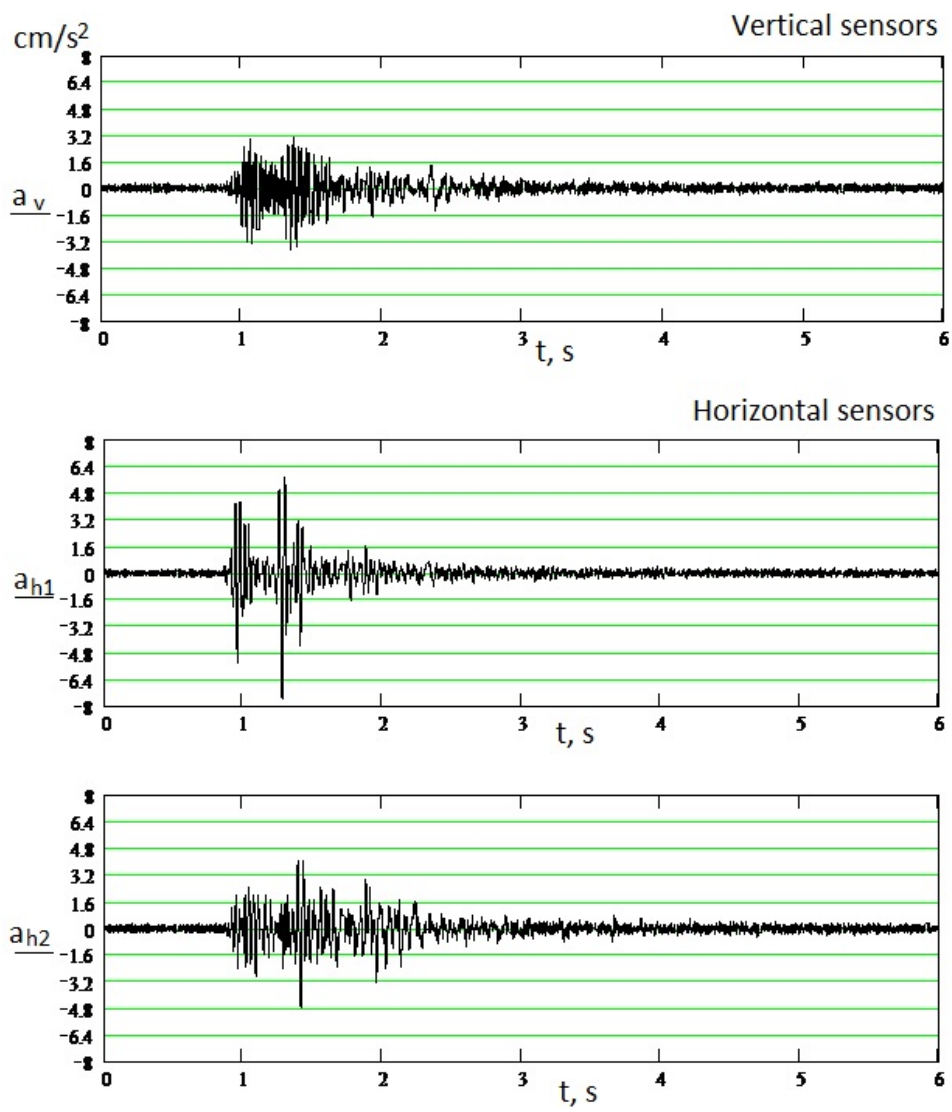

Figure 13 Acceleration seismograms of ground surface vibration at the recording point at the college after the production blast 

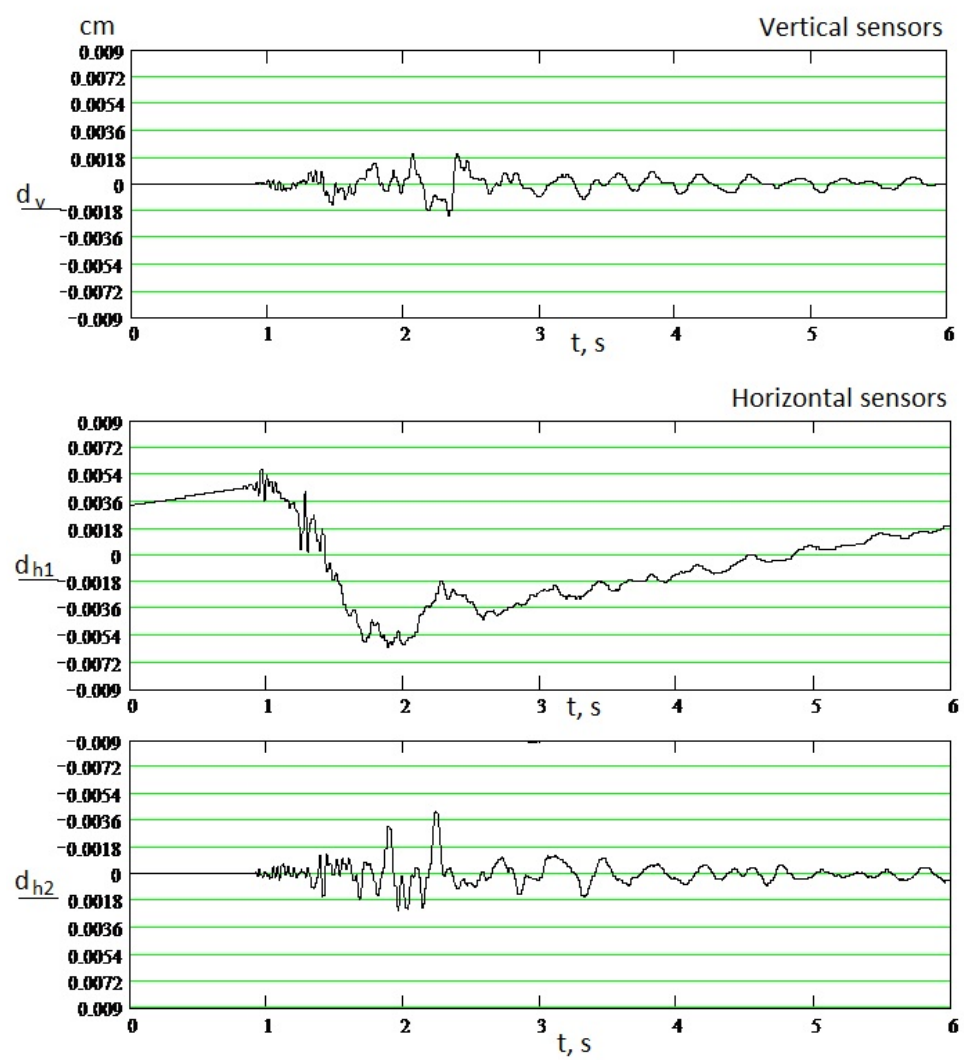

Figure 14 Displacement seismograms of ground surface vibration at the recording point at the college after the production blast

For the horizontal vibration in the direction towards the production blast, it is typical that maximum vibrations have frequencies of $2.5,6,9$ and $10 \mathrm{~Hz}$. For the horizontal north-southward vibrations, the maximum vibrations vary in a wide range with the frequencies of $1,2.5,3.5,5,6,7,9$ and $10 \mathrm{~Hz}$. The maximum velocities of the vertical and horizontal vibrations are cited in Table 2 .

Table 2 Maximum velocities of seismic vibration

\begin{tabular}{|c|c|c|c|}
\hline $\begin{array}{l}\text { Date of } \\
\text { recording } \\
\text { (weight of } \\
\text { explosive in } \mathrm{kg} \text { ) }\end{array}$ & $\begin{array}{l}\text { Point of seismic } \\
\text { recording (distance } \\
\text { to the blasting site } \\
\text { in metres) }\end{array}$ & $\begin{array}{l}\text { Maximum velocity } \\
\text { of seismic } \\
\text { vibration }(\mathrm{cm} / \mathrm{s})\end{array}$ & Orientation of seismic vibration \\
\hline \multirow{6}{*}{$\begin{array}{l}6 \text { July } 2014 \\
(49,200)\end{array}$} & \multirow{3}{*}{$\begin{array}{l}\text { Railway station } \\
\text { (640) }\end{array}$} & 0.12 & Vertical \\
\hline & & 0.12 & $\begin{array}{l}\text { Horizontal, towards the blast } \\
\text { (north-southward) }\end{array}$ \\
\hline & & 0.12 & $\begin{array}{l}\text { Horizontal, at right angle to the direction } \\
\text { towards the blast (west-eastward) }\end{array}$ \\
\hline & \multirow[t]{3}{*}{ College $(4,230)$} & 0.12 & Vertical \\
\hline & & 0.08 & $\begin{array}{l}\text { Horizontal, towards the blast } \\
\text { (west-eastward) }\end{array}$ \\
\hline & & 0.05 & $\begin{array}{l}\text { Horizontal, at right angle to the direction } \\
\text { towards the blast (north-southward) }\end{array}$ \\
\hline
\end{tabular}


In the three directions, the velocities of seismic vibration of ground surface have tolerable values. The maximum velocity of ground surface vibrations makes $0.12 \mathrm{~cm} / \mathrm{s}$, which is 8.3 times lower than the maximum permissible value of $1 \mathrm{~cm} / \mathrm{s}$.

After the large-scale blast, the explosive equivalent was $74.1 \mathrm{t}$ as per the formula:

$$
P_{\text {eqv }}=10 \log A_{\max }-0.1 /-.9 t
$$

The blast energy class was $7.4\left(2.8 \times 10^{7} \mathrm{~J}\right)$; the energy class was $\log \mathrm{E}$, where $\mathrm{E}-$ the seismic energy in the blast source: $\mathrm{E}=10^{\mathrm{K}}$ and $\mathrm{K}=$ logt $\times 2.76+2.24$. The overall duration of the recording was $77 \mathrm{~s}$. The recorded seismic aftershocks had energy from 10 to $2 \times 10^{7} \mathrm{~J}$ (Figure 15). Large aftershocks with the energy of $3.6 \times 10^{3} \mathrm{~J}$ and $10^{5} \mathrm{~J}$ were monitored in crosscuts 2 and 3 (west). Weak aftershocks with the energy of $10-10^{2} \mathrm{~J}$ were felt in crosscuts 1 and $2-5$. A shock with the energy of $2 \times 10^{7} \mathrm{~J}$ took place beyond the mine field nine hours after the blast (Figure 16).

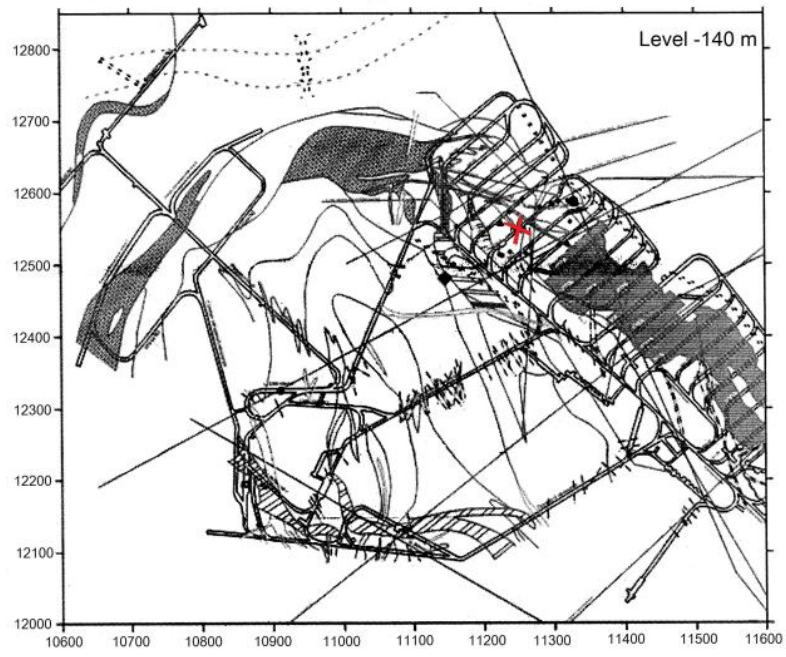

Figure 15 Distribution of shocks in the mine field under production blasting; $\times$ is the source of the blast

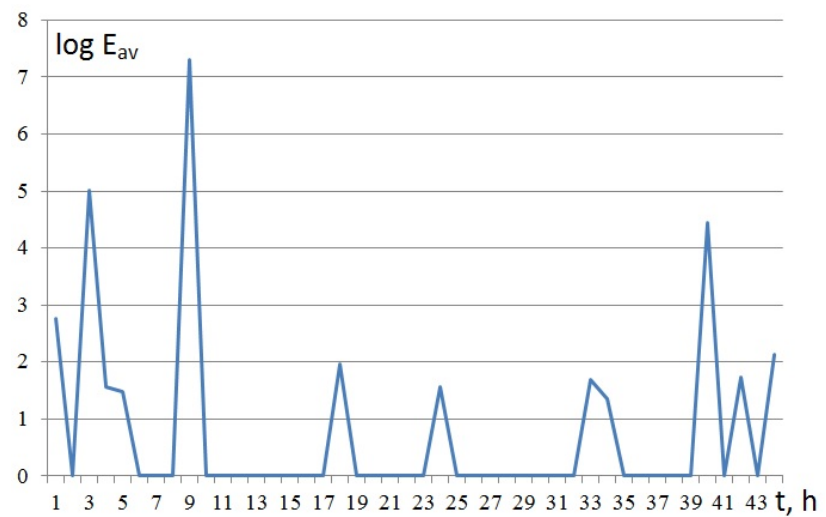

Figure 16 Time distribution of aftershocks after the production blast

Thus, according to the estimation of seismic effect exerted by a production blast on the blasting site vicinity, the maximum velocity of ground surface vibration is $0.12 \mathrm{~cm} / \mathrm{s}$, which is 8.3 times less than the permissible value, the seismic energy of shocks ranges between $3.6 \times 10^{3}$ and $10^{5} \mathrm{~J}$, and shocks beyond the bounds of the mine field have the energy of $10^{7} \mathrm{~J}$.

\section{Conclusion}

It has been found that in difficult ground conditions of iron ore mining in Western Siberia, tectonic fracturing is widely developed and higher horizontal stresses vary from 1.4 to 2.6 times the vertical stress. 
Exploitation of ore reserves is carried out at depths of 800-100 m below the ground surface using different technologies: level caving at a level height of $60-80 \mathrm{~m}$; room-and-pillar mining and sublevel caving with the heights of a level and a sublevel of 70-80 and $35 \mathrm{~m}$, respectively.

Using the system of level caving with closely spaced blastholes of different diameters has halved the yield of overbreak and yield of oversized rock fragments, and has increased ore production output per $1 \mathrm{~m}$ of drilling by $25 \%$.

With the top-downward system of mining in a blind, thick rockburst-hazardous orebody, it has been succeeded to reduce the amount of development and preparation drivage by 1.5-2 times at the enhanced stability of span in the mined-out void owing to alternating arrangement of rooms and pillars $20 \times 20 \mathrm{~m}$ in size and due the subsequent transition to sublevel caving.

The developed and assumed blasting design includes determination of powder factor per each explosive charge and short delays of blasting across the orientation of principal stresses, which enables reduction in powder factor by $10-15 \%$, improvement of quality of rock fragmentation by blasting and mitigation of seismic load on the surrounding rock mass.

\section{References}

Ashurkov, VA 1971, 'Deep faults in the area of Gornaya Shoria by the geophysical data. Problems of tectonics in the Altai-Sayan mountainous region', Scientific Conference Proceedings, Novokuznetsk, pp. 29-40.

Eremenko, AA, Melnichenko, VF, Bashkov, VI \& Gakhova, LN 2015, 'Geomechanical evaluation of engineering solutions for a new variant of mining system for Sheregesh deposit', Kuzbass State Technical University Bulletin, no. 6, pp. 25-32.

Eremenko, AA, Filippov, VN, Gaidin, AP \& Mashukov, IV 2002, 'Experience of a large-scale production blast implemented under conditions of high rock pressure in Sheregesh mine', Mining Information and Analysis Bulletin, no. 1, pp. 92-94.

Eremenko, AA, Filippov, VN, Kulikov, VI \& Mashukov, IV 2005, 'Seismic effect of developing blasts in rockburst-hazardous mines,' Bulletin of the Russian Academy of Natural Sciences, Western Siberia Division, issue 7, pp. 148-158.

Glozman, LM, Makovskaya, NA, Izofov \& VO 1982, Definition of Limit Vibrations for Guarded Objects during Blasting Fragmentation of Understructures and Building Failure under Rebuilding Operations. RTM 36.22.91, Nedra, Moscow.

Kalugin, AS, Kalugina, TS \& Ivanov, VI 1981, Iron Ore Deposits in Siberia, Nauka, Novosibirsk.

Kurlenya, MV, Eremenko, AA \& Bashkov, VI 2014, 'Role of blasting in generation of seismic and dynamic events in ore mines', Mining Journal, no. 12.

Kuznestov, VA 1952, 'Main phases in geotectonic evolution in the south of the Altai-Sayan mountainous area', Transactions of the West-Siberian Branch of the USSR Academy of Sciences, no. 12.

Kuznetsov, VA 1963, Tectonic zoning and features of endogenetic metallogeny in Gorny Altai. Gorny Altai geology and metallogeny problems', Transactions of the Institute of Mining, Siberian Branch, USSR Academy of Sciences, no. 13.

Mashukov, IV 2014, 'Recording of seismic vibrations generated by large-scale underground blasting,' Mining Information and Analysis Bulletin, no. 4, pp. 216-221.

USSR State Committee on Construction 1985, Construction Norms and Regulations SNiP 2.01.07-85. Loads and Effect, USSR State Standard 25100-82. 